\title{
Media as a Production and Distribution of Information: The Concept of Media Economy
}

\author{
Dr. Khalid Sultan \\ Assistant Professor, Department of Communication Studies \\ College of Applied Sciences, Nizwa, \\ Ministry of Higher Education, Sultanate of Oman \\ E-mail: khalid_sultan.niz@cas.edu.om
}

Dr Mirza Jan

Associate Professor, Department of Mass Communication

Gomal University, D. I. Khan, Pakistan

E-mail: mirzajan_70@yahoo.com

\begin{abstract}
Dr. Sajjad Ahmed Paracha
Assistant Professor, Department of Media Studies

The Islamia University of Bahawalpur, Pakistan

E-mail: drparacha_mediastudies@iub.edu.pk
\end{abstract}

Accepted: August 05, 2012 Published: September 22, 2012

Doi:10.5296/ijhrs.v2i3.2295 URL: http://dx.doi.org/10.5296/ijhrs.v2i3.2295

\begin{abstract}
This paper reviews the existing concepts on media that produce and distribute the information. Media sector present the highly unpredictable process among the audience. Media Economy is a best concept of understanding to see the media firms \& industries. Media concentrate on the ownership and on the influence of advertisers' owning companies. Structures and economics explain the media industry and developments in the market. This review paper discusses the rise the media economy for knowing microeconomics underpinning.
\end{abstract}

Keywords: Media, Economy, Production, Distribution, Means of Communication 


\section{Introduction}

Media refers to the "means of communication that reach large numbers of people, such as television, newspapers, and magazines and radio (Armstrong, 2000). Thus, the media sector is concerned with the production and distribution of information on a one-to-many basis. The characteristic of audiences is that the production process is highly unpredictable. This is due in large part to the fact that the audience product is produced from raw materials that the producers can not effectively control. Mass media and the related fields of advertising, telecommunications and other aspects of the "information society" are growing in importance, both in terms of their economic and socio-political significance in society. The Media Economy is a good description of how macroeconomic principles can be used to understand and analyze media firms and industries. It provides a framework for standardizing the analysis of a media company in the way that other firms are analyzed (Routledge, 2010).

Media economics involves the application of economic theories, concepts, and principles to study the macroeconomic and microeconomic aspects of mass media companies and industries. Concomitant with the increasing consolidation and concentration across the media industries, media economics emerged as an important area of study for academicians, policymakers, and industry analysts. The challenges posed by this unpredictability of audience behavior are compounded when we consider the inherent perishability of media audiences. Unlike media content, which can be sold and resold indefinitely (Owen \& Wildman 1992), the shelf life for media audiences is exceptionally short, lasting only for the duration of time that a media product is consumed. There have been a lot of mergers and buyouts of media and entertainment companies since the 1980s. Mainstream media has since become more concentrated in terms of ownership and the influences of advertisers and owning companies both have an enormous in how mainstream media shapes itself and society. Regular study of media economic issues began in the 1970s but flourished in the 1980s with the addition of classes on the subject and U.S. and European universities.

\section{Who Owns The Media?}

The public choice theory holds that a government-owned media outlet would distort and manipulate information to entrench the incumbent politicians, preclude voters and consumers from making informed decisions, and ultimately undermine both democracy and markets. Because private and independent media supply alternative views to the public, they enable individuals to choose among political candidates, goods, and securities - with less fear of abuse by unscrupulous politicians, producers, and promoters (Amartya, 1984). Moreover, competition among media firms assures that voters, consumers, and investors obtain, on average, unbiased and accurate information.

To understand the basic facts about media ownership, and to evaluate these predictions, we collect data on ownership patterns of media firm's newspapers, television, and radio in 97 
countries. Our paper provides a first systematic look at the extent of state and private ownership of media firms around the world, of the different kinds of private ownership, and of the prevalence of monopoly across countries and segments of the media industry. Our basic finding is that the two dominant forms of ownership of media firms around the world are ownership by the state and ownership by concentrated private owners, namely, controlling families.

Ownership, of course, is not the only determinant of media content. In many countries, even with private ownership, government regulates the media industry, provides direct subsidies and advertising revenues to media outlets, restricts access to newsprint and information collection, and harasses journalists. We discuss these modes of control as well. Within countries, we select media outlets on the basis of market share of the audience and provision of local news content for the year 1999. This approach focuses on who controls the majority of information flows on domestic issues to citizens. We exclude entertainment and sport media, as well as foreign media outlets, if they do not provide local news content. Throughout the world, governments regulate media using measures ranging from content restrictions in broadcasting licenses to constitutional freedom of expression provisions. The types of regulations and their enforcement vary significantly within our sample countries.

Structure and Economics: It seeks to define and explain the structure and workings of the media industry and to explore trends and developments in the market. This is being accomplished by examining the market's structure including the amount and strength of competition, conditions of entry and cost factors, including the amount and strength of competition, capital equipment and facilities costs, labor costs, distribution costs, and policies and regulations. The research is also documenting levels of economic concentration and ownership concentration by media industries and in the media and communications branch. The researchers have identified four media eras during the last half of the twentieth century:

- before to 1957: The Era of Print and Universal

Public Service Radio

- 1957 to 1970: The Era of Public Service Television

and Popular Public Service Radio

- 1970 to 1985: The Era of Commercialization

- 1985 to present: The Era of Media Businesses

Media Conduct: The second dimension of the study is focusing on operational factors and strategies. It is exploring the manner in which consumers have chosen to spend funds and time in the rapidly changing communications environment and the effects of the choices on individuals. It is also identifying trends and issues and the cultural and national public policy implications of these private choices.

Media Content: The third dimension of this project is documenting the overall content profiles of Finnish media, identifying and assessing the range and amounts of topics covered and the forms of presentation utilized in the media. This research will reveal the impact of the changing communications environment on media pluralism. 


\section{Review of Literature on Media Economics}

The rise of the mass media paved the way for the study of media economics. Research began to emerge during the 1950s. The media industries provided all of the elements required for studying the economic process. Many of the early media economists addressed microeconomic concepts. Ray $(1951,1952)$ examined newspaper competition and concentration, whereas Reddaway (1963) reviewed economic characteristics of newspapers as firms. Steiner's (1952) classic work on competition in radio involves the application of microeconomic concepts to the radio industry. Early studies of the television industry examined market structure (Levin, 1958), competition with other media (Berlson, 1961), and the impact on advertising revenues (Tijmstra, 1959-1960).

Many economists have noted, media content is a fairly distinctive product, with a number of important distinguishing characteristics. For instance, the "public good" nature of media content has been the subject of extensive analysis (Owen \& Wildman 1992). As a public good, media content is not "used up" in consumption.

Concentration of ownership has been another topic studied across media industries. Representative studies of media concentration across industries include Albarran and Dimmick (1996), Bagdikian (2000), and Compaine (1985b), along with specific studies of industry concentration in newspapers (Lacy, 1984, 1985; McCombs, 1988; Picard, 1982, 1988a; Rosse, 1980), broadcast television (Bates, 1993; Litman, 1979), motion pictures (Gomery, 1993), and trade books (Greco, 1993).

Ownership structure has been examined in regard to management policy in the newspaper industry. Key works include Blankenburg's $(1982,1983)$ research on controlling circulation costs and pricing behavior and the impact on financial performance (Blankenburg \& Ozanich, 1993). Further inquiry into press ownership and competition continues to develop, including the market for online newspapers (see Chyi \& Sylvie, 2001; Lacy, Shaver, \& St. Cyr, 1996; Lacy \& Simon, 1997). Other studies have examined variables such as media competition (Compaine, 1985a; Dimmick \& Rothenbuhler, 1984), consumer expenditures and the principle of relative constancy (McCombs, 1972), barriers to entry (Wirth, 1986), demand (Busterna, 1987; Lacy, 1990), and utility (Albarran \& Dimmick, 1993; Dimmick, 1993).

\section{Theoretical Consideration of Media Economics}

Theoretical development relates to media concentration. In the United States, antitrust laws are designed to promote competition and limit concentration, making this an important area of inquiry for both public and social policy. Media concentration is usually examined in one of two ways. Researchers gather existing data on firm/industry revenues to measure the degree of concentration by applying different methodological tools (e.g., concentration ratios, 
indices, or the Lorenz curve (Albarran, 2002), or researchers track concentration of ownership among the media industries ( Bagdikian, 2000; Compaine \& Gomery, 2001; Howard, 1998). Regardless of the methods used, research documents increasing consolidation across all areas that make up the media industries, with many industries reaching "highly concentrated" status, indicating that the industry is dominated by a handful of firms (Albarran, 2002; Albarran \& Dimmick, 1996).

\subsection{Forces Driving Media Industry}

Media executives speak in the language of war — of bombarding audiences, targeting markets, capturing grosses, killing the competition, and winning, by which they mean making more money than the other guy. Some news organizations even refer to their employees as "the troops". It is hard for media workers, including journalists, to operate outside the ethos of hyper-competition and ratings mania. As willing or unwilling conscripts in the media war, journalists imbibe its values and become warriors themselves. These four forces consist of technology, regulation, globalization, and sociocultural:

\subsection{Technology}

Because media industries are heavily dependent on technology for the creation, distribution, and exhibition of various forms of media content, changes in technology affect economic processes between and within the media industries. There are three critical areas where technology has done this. The first is the initial evolution of computers. Computing technology improved efficiency among workers in many areas and greatly minimized storage requirements for paperwork as well as increasing opportunities for communication (e-mail) and other software applications. The second technological area, coupled with the rise of computing technology, has involved the transition from analog to digital content. As computers became more powerful and sophisticated, the ability to convert text and graphics digitally soon led to digital audio and video files developments.

The media industries quickly moved to converting to a digital world, first in print and later in electronic media. The third area of technological impact was and continues to be with the development of the Internet. First used primarily to exchange textual information, the advent of hypertext language led to the development of the World Wide Web, forever changing the user's experience with the Internet. Some media companies quickly recognized the power of the Internet, building Web sites to attract consumers and advertisers, whereas other companies floundered in their initial attempts to understand how best to use the new medium. The Internet offers media companies another way to connect audiences and advertisers, as well as a means to build and enhance brand development.

\subsection{Regulation}

Regulatory actions can always affect competitive market forces, and media industries are no exception. During the 1980s and 1990s, U.S. media industries benefited from a combination 
of deregulatory actions as well as liberalization of former policies. The 1996 Telecommunications Act, the most significant U.S. communications regulation passed since 1934, sought to eliminate competitive barriers in the broadcast, cable, and telecommunication industries. Ownership caps were relaxed yet again, and companies operating in one industry could now compete in others (e.g., cable companies could now offer telephone service, and telephone companies could offer cable-like services). If eliminated, the cross-ownership rules would give publishing companies the opportunity to acquire broadcast stations and cable systems within the markets they serve, leading to the development of multi-media-based companies offering content and advertising across multiple mediums.

\subsection{Globalization}

With many American media markets heavily saturated, the global marketplace has become even more important in generating revenues for media firms and industries. Media products are often created with global audiences in mind, which is why so much content contains sex and violence - two topics that are easily understood across cultures. Globalization presents a challenge for media economics researchers, as accounting practices and regulatory structures differ from country to country.

There are few reliable sources of global financial data related to media. Nevertheless, it is critical that scholars recognize that media companies compete and operate in a global as well as domestic marketplace for audience share and advertiser revenues. media content is often created with the desire to reach global audiences, so consumer tastes and preferences are critical in understanding audience needs and wants. Audiences have an insatiable appetite for media-related content and services. As people live longer and obtain more discretionary income, spending on media will likely rise. These shifts in audience composition and makeup will present new pressures on media firms to develop content that will appeal to these unique and differing audiences.

\section{MEDIA PRODUCTS}

Media content, in the form of television programs, movies, sound and video recordings, and print (e.g., books, magazines, newspapers), represents some of the products supplied by media firms. Media products can be broadly classified into categories of information (news-related content) and entertainment (drama, comedy, action, music, games, etc.). Massive consolidation across the media industries has given rise to vertically integrated conglomerates (meaning they control many aspects of production, distribution, and exhibition) such as Viacom, AOL Time-Warner, Disney, and News Corporation. Media products such as television programming, feature films, and sound recordings can be repeatedly used and marketed to both audiences and advertisers, forming the "dual-product marketplace."

Many media industries function in a dual-product marketplace. That is, media firms produce or supply information and entertainment products that are consumed or demanded by 
audiences and, in most cases, advertisers. The dual-product marketplace is a unique characteristic of the media industries, allowing for separate transactions and potential revenue streams from both audiences and advertisers. Media firms try to strategically position their content so as to maximize potential revenues. The number one priority of media executives and managers is to generate positive cash flow (revenues less expenses, depreciation, taxes, and interest) to increase the value of their firm.

\section{Conclusion}

Other issues affecting our understanding of the media economy are not just those in the media field. Each week, new technologies and new products find uses as communication tools. Facebook, Twitter, or Four Square was designed as tools for social networking. Additionally, however, they are being used as tools to spread news and information. They have become an essential part of the media economy - not only because of their large individual valuations, but also because of how they continue to disrupt the revenue streams of the firms that are the main unit of analysis of this book. Studying the media economy means we also need to study the technology economy.

The handful of dominant corporations have pursued quick, ever higher profits, mainly by producing more trivialized and self-serving commercialized news. Their entertainment, with its powerful impact on the popular culture, has become further coarsened and brutalized. As each use of shock-as-attention-getter becomes bolder, more barriers have fallen. Main media talk shows and entertainment have vulgarized language as a ratings technique, introducing changes that go beyond the inevitable evolution of all language in modern societies. New terms have always emerged for new phenomena and experiences. The cyber world, for example, has invented words because the Internet and its offshoots need new words to describe what never existed before. Advertisers and adolescents have always invented their own novel jargon.

In the beginning, the Internet was celebrated as a welcome liberation of the individual from powerful mass media systems. Anyone with a computer and a modem connection to the outside electronic world has access to the growing vastness of the new medium. Individuals expressing themselves on the Internet are provided gratification of being one voice among thousands. Civic bodies and an unlimited variety of propagandistic groups and individuals can display their goals and values at less expense than ever before and have a potentially large-if mostly anonymous and uncertain--audience. Internet's e-mail, with its own cyber address system for each participant, permits private messages that are close to instantaneous and permits replies at the same speed.

But with each passing month, the balance in favor of the individual looks less reassuring. Thanks to the Internet's heavy presence of corporations, intrusive advertising, and other highly orchestrated business displays designed to be seen by millions, the individual's private Internet space is continually invaded by electronic sales pitches. And on-line commerce has 
its share of fraudulent or ludicrous ads, like ads for the nonexistent vitamins F, P, T, and U, presented as cures for everything from sexual dysfunction to leg cramps. As the dominant corporations' increasing global scale enlarged their importance in the stock market, Wall Street analysts and leading investment houses became a factor in deciding how much and what kind of news and entertainment will reach the public.

\section{References}

Alan, b. Albarran. (2010). The Media Economy New York: Routledge, ISBN 978-0415990462

Armstrong, M. (2000). "Converging communications: implications for regulation", Speech at The Beesley Lectures: Lectures on Regulation Series X, 14 November 2000.

Amartya, Sen. Poverty and Famines. (1984). Amartya Sen, Development as Freedom (1999); Timothy Besley \& Robin Burgess, The Political Economy of Government Responsiveness: Theory and Evidence from India, 117 Q. J. Econ. 1415 (2002); and Timothy Besley \& Andrea Prat, Handcuffs for the Grabbing Hand? Media Capture and Government Accountability (CEPR Discussion Paper No. 3132, London 2002)

Albarran, A. B. (2002). Media economics: Understanding markets, industries and concepts (2nd ed.). Ames: Iowa State University Press.

Albarran, A. B., \& Dimmick, J. (1993). Measuring utility in the video entertainment industries: An assessment of competitive superiority. Journal of Media Economics, $6(2), 45-51$.

Albarran, A. B., \& Dimmick, J. (1996). Concentration and economies of multiformity in the communication industries. Journal of Media Economics, 9(4), 48-49.

Bagdikian, B. H. (2000). The media monopoly (6th ed.). Boston: Beacon.

Bates, B. J. (1993). Concentration in local television markets. Journal of Media Economics, 6(1), 3-22.

Berlson, W. A. (1961). Effects of television on the reading and buying of newspapers and magazines. Public Opinion Quarterly, 25, 366-381. 
Blankenburg, W. R. (1982). Newspaper ownership and control of circulation to increase profits. Journalism Quarterly, 59, 390-398.

Blankenburg, W. R. (1983). A newspaper chain's pricing behavior. Journalism Quarterly, 60, 275-280.

Blankenburg, W. R., \& Ozanich, G. W. (1993, Spring). The effects of public ownership on the financial performance of newspaper corporations. Journalism Quarterly, 70, 68-75.

Busterna, J. C. (1987). The cross-elasticity of demand for national newspaper advertising. Journalism Quarterly, 64, 287-291.

Chyi, H. I., \& Sylvie, G. (2001). The medium is global, the content is not: The role of geography in online newspaper markets. Journal of Media Economics, 14(4), 231-248.

Compaine, B. M. (1985a, Summer). The expanding base of media competition. Journal of Communication, 35, 81-96.

Compaine, B. M. (1985b). Who owns the media? Concentration and ownership in the mass communications industry (2nd ed.). White Plains, NY: Knowledge Industry Publications.

Compaine, B. M., \& Gomery, D. (2001). Who owns the media? (3rd ed.). Mahwah, NJ: Lawrence Erlbaum. Media Economics 305

Dimmick, J. (1993). Ecology, economics, and gratification utilities. In A. Alexander, J. Owers, \& R. Carveth (Eds.), Media economics: Theory and practice (pp. 135-156). New York: Lawrence Erlbaum.

Dimmick, J., \& Rothenbuhler, E. (1984, Winter). The theory of the niche: Quantifying competition among media industries. Journal of Communication, 34, 103-119.

Gomery, D. (1993). The contemporary American movie business. In A. Alexander, J. Owers, \& R. Carveth (Eds.), Media economics: Theory and practice (pp. 267-281). New York: Lawrence Erlbaum.

Greco, A. N. (1993). Publishing economics: Mergers and acquisitions in the U.S. publishing industry: 1980-1989. In A. Alexander, J. Owers, \& R. Carveth (Eds.), Media economics: Theory and practice (pp. 205-224). New York: Lawrence Erlbaum. 
Howard, H. H. (1998). The 1996 Telecommunications Act and TV station ownership: 1 year later. Journal of Media Economics, 11(3), 21-32.

Lacy, S. (1985). Monopoly metropolitan dailies and inner-city competition. Journalism Quarterly, 62, 640-644.

Lacy, S. (1990). A model of demand for news: Impact of competition on newspaper content. Journalism Quarterly, 67, 40-48, 128.

Lacy, S., Shaver, M. A., \& St. Cyr, C. (1996). The effects of public ownership and newspaper competition on the financial performance of newspaper corporations: A replication and extension. Journalism Quarterly, 73, 332-341.

Lacy, S., \& Simon, T. F. (1997). Intercounty group ownership of daily newspapers and the decline of competition for readers. Journalism Quarterly, 74, 814-825.

Levin, H. J. (1958). Economic structure and the regulation of television. Quarterly Journal of Economics, 72, 445-446.

Litman, B. R. (1979). The television networks, competition and program diversity. Journal of Broadcasting, 23, 393-410.

McCombs, M. E. (1988). Concentration, monopoly, and content. In R. G. Picard, J. P. Winter, M. McCombs, \& S. Lacy (Eds.), Press concentration and monopoly: New perspectives on newspaper ownership and operation (pp. 129-137). Norwood, NJ: Ablex.

Owen, B. M., \& Wildman, S. (1992). Video economics. Cambridge, MA: Harvard University Press.

Picard, R. G. (1982, April). Rate setting and competition in newspaper advertising. Newspaper Research Journal, 3, 3-13.

Picard, R. G. (1988a). Measures of concentration in the daily newspaper industry. Journal of Media Economics, 1(1), 61-74.

Ray, R. H. (1952). Economic forces as factor in daily newspaper competition. Journalism 
Quarterly, 29, 31-42.

Reddaway, W. B. (1963). The economics of newspapers. Economic Journal, 73, 201-218.

Rosse, J. N. (1980, Spring). The decline of direct newspaper competition. Journal of Communication, 30, 65-71.

Steiner, P. O. (1952, May). Program patterns and preferences, and the workability of competition in radio broadcasting. Quarterly Journal of Economics, 66, 194-223.

Tijmstra, L. F. (1959-1960, Winter). The challenges of TV to the press: The impact of television on advertising revenues and circulations of newspapers. Journal of Broadcasting, 4, $3-13$.

Wirth, M. O. (1986). Economic barriers to entering media industries in the United States. In M. McLaughlin (Ed.), Communication yearbook 9 (pp. 423-442). Beverly Hills, CA: Sage. 